\title{
Russian National Social Security System as the Condition of Pensioners' Well-Being
}

\author{
S.L. Eremina ${ }^{a, b *}$, Fu Sun $^{a}$, O.V.Kudelina ${ }^{b}$, F.G. Babaeva ${ }^{a^{*}}$ \\ * Corresponding author: Eremina S.L., esofia@tpu.ru \\ ${ }^{a}$ National Research Tomsk Polytechnic University, Lenina Ave.,30, Tomsk 634050, Russia; E-mail address: esofia@tpu.ru, Tel.: \\ $+7-903-952-3276$ \\ ${ }^{b}$ Siberian State Medical University, Moscow highway,2,Tomsk 634050, Russia, E-mail address: feuzozz@yandex.ru, Tel.: +7- \\ 953-914-2278
}

http://dx.doi.org/10.15405/epsbs.2016.02.30

Pensioners' well-being depends on many factors. It can be provided with the state, family, and pensioners themselves. It can be tangible and intangible. This research is limited with the following frames: only material well-being, only governmental support, 8 federal districts of the Russian Federation, the exploration period is 6 years: 2006-2011. The evaluation of 6 activities by MinMax Method, including three cash ones and three "noncash" ones, allowed to prove empirically the hypothesis that social support of pensioners living in various federal districts of the Russian Federation is significantly different. Leveling out of these differences should be a crucial way to perfect/improve pensioners' social support.

(C) 2016 Published by Future Academy www.FutureAcademy.org.uk

Keywords: Well-being, pensioners, social support, federal district, the Russian Federation, MinMax.

\section{Introduction}

Economists use the term "welfare" as a synonym for "well-being" or "social welfare" more often than they used to do, i.e. the state of happiness and contentment including their living standard in the material meaning. In this context "welfare" is closer to the country on the whole, and the "well-being" - to a person. If we keep in mind the nineteenth and twentieth centuries, the main purpose of "wellbeing" or "social welfare" of senior citizens was the decline of poverty and the reduction of inequalities.

Many authors have been exploring issues of relative inequality, particularly happiness and wellbeing. There are even some of them who write about the abuse and even the neglect of older people 
(Jamaluddina, 2015). Other ones connect well-being with the environment and, in particular, with the clean air (Mabahwi, 2014). In Russia the regional differences in poverty and related social inequalities have become the basis of community study conducted in March - April 2013 (http://www.isras.ru/analytical_report_bednost_i_neravenstva.html). Crucial indicators of well-being according to older people's point of view are:

-enough material support,

- splendid health,

- personal potential of participation in society.

In the twenty-first century healthy lifestyle promotion, health system activity, improving ecological situation, and many other factors both in the world and in Russia have led to the increase in the length of life, as the result, the load on the pension system increased and social security became the largest item of the state budget 1 .

Budget expenditures on social security of older people make up, on average, more than 50\% (3.3\% of GDP), but it is different from one region to another; they equal to $11.1 \%$ - in Western Europe; $8.3 \%$ - in Central and Eastern Europe; 6.6\% - in North America; 4.6\% - in Latin America; 2.0\% - in the Middle East, Asia and the Pacific (where the proportion of the elderly population is high); $1.3 \%$ - in Africa (where the proportion of older people is low).

Most often "Pension and social" assistance are distinguished by:

- gender,

- the basis of residence (urban or rural),

- the income level of a citizen (for example, in accordance with the law in Russia for accrued pension is taken salary not exceeding 1.6 of the average salary)

- the income level of a country (high, medium or low GDP per capita)

- work in one or several organizations, etc.

In the federal state differences can also depend on the residence in the territory of the federal district. In this context issues sound almost rhetorical: whether equal well-being of pensioners should be provided with living in different areas of the federal state (a constituent entity, territorial districts, etc.); whether the well-being of pensioners has only a public function or particular topics depend on pensioners themselves; whether citizens of working age should take care of their well-being level as well as life endures, for example worrying about the health and the future income; if they can do it?

\section{The purpose of the work}

We do not set the mission to determine what should be the degree of the state participation and some citizen retirement age to ensure well-being. The purpose of the research is to prove the key direction of improving the state social policy - the need for leveling the variation in levels of the state social support based on the differences found in the level of state social support of senior Russian citizens depending on the area of residence (a federal district). 


\section{Methodology}

Realizing that there are several sources of providing well-being pensioners: state, personal contribution, family, welfare funds, church and etc., in this study we emphasize the only source - the state; the case study is the Russian Federation.

Using the data from the Federal Statistics of the Russian Federation (http://www.fedstat.ru/indicator/data.do) for the period 2006-2011 (6 activity, including 3 - "money" ones and 3 - conditionally "non-cash" ones), we characterize some aspects of material well-being of pensioners in 8 federal districts2. We rank indicators to federal districts into the scale from 1 to 10 using Minimax - a method that allows translating statistical information into the coefficient and comparing the activity with different units (people, rubles, etc.). Next, we summarize findings and compare them with the waiting index of material well-being, as calculated by the method of Minimax. This will allow finding out differences in the level of well-being retired federal districts, comparing with its expectations of pensioners and it can serve as a basis to improve policy of the state support for senior citizens - leveling the differences in this parameter, depending on the area of the pensioner's residence.

\section{Discussion}

Well-being of the people, but not just it is economic indicators GDP per capita, became the basis for the measurement of human development. (www.oecdbetterlifeindex.org) It is measured, in particular, by the expected lifespan, education, factor of personal safety and inequality, including "inequality of incomes measured by its distribution per capita". Some experts (Hagemejer, 2005) also take into account non-material parameters of well-being.

The older people's right of social protection and adequate standard of living for the health support and well-being including medical care and necessary social services are set forth by the main international instruments:

1. Universal Declaration of Human Rights (1948).

2. International Covenant on Economic, Social and Cultural Rights (1967).

3. Standards of the International Labour Organisation (ILO) - advice to countries to drive the older people's rights to social security from baseline levels to full realization: the Convention № 102 (1952); Convention № 128; Recommendation № 131 (1967); Recommendation № 202 (2012).

These documents establish the guaranteed level of old-age pensions for retirement and their regular indexation to maintain the purchasing power of pensioners. In particular, the Convention №102 (Art. 67 (a)) and №128 include the provision of guaranteed income for people who have reached retirement age, through the income associated with contribution (the size of the minimum benefit or reproduction rate which equals to the certain percentage of past earnings, particularly low-paid citizens) and / or base rate, extraneous with contribution and which can be either universal or determined by the poverty level. The minimum level of the last should be determined as a proportion of average earnings of an ordinary worker [30], but "the total amount of allowances and other available funds ... should be sufficient to leave the family in the field of health protection and dignity." 
Recommendation №202 (Part II, para. 5 (a)) gives priority to those who need and are not covered by existing schemes to ensure the protection of basic income for all elderly people. This guarantee is valid as the protection against poverty, helplessness and social isolation in old age for people who are not covered by pension fund scheme, generated from the income in the period of labor activity.

Material security in the elderly age, especially through increased pension fund scheme, is different from country to country. Help Age International is rated by Global Age Watch Index which helps to measure and evaluate the support of the elderly population and point at the necessity of the appropriate state policy. The index shows that the policy of support for senior citizens in the form of pensions, the creation of conditions of education and employment, free access to health services, as well as public transport should be more systematic.

In 2013 Russia occupied the 65th place among 96 countries, including the 26th place - by the "personal potential" criterion (employment and education), 37 - by the "material security" (pension fund scheme, poverty level, relative welfare, the per capita GDP), 82 - by the "enabling environment" (social intercourse, physical security, civil liberty, access to public transport), and 86 - by the "health status" (length of life about 60 years, length of healthy life about 60 years, mental health) (Global Age Watch Index, 2014) . All this, despite the fact that the proportion of Russian people is over 60 years, equals to $19.4 \%$. Among the 20 countries of the Eastern Europe, the proportion of people older than 60 years is olwer only in three countries: Moldova (17.7\%), Albania (15.7\%) and Armenia (14.7\%) (2013). Thus, indicators enabling environment and the health of older Russians significantly reduce Russia's rating. Their growth is undoubtedly the key task of the Government.

Regional rating Natixis Global Retirement Index found that the best place for those who had retired is European countries (http://www.euromag.ru/catalogs/stat/30691.html ).

The World Bank (2014), discussing the challenges faced by pension systems in Europe and Central Asia in connection with the demographic situation (increase length of life, decline in birth rate and migration), describes the pension system as the inverting pyramid in the sense that if earlier retirees were under the working age, now the lowest ratio decreased significantly. Nowadays in general for 3.5 people it is one elderly person; in some countries - only three. According to forecasts, the proportion of senior citizens consisting of population in countries with both low- and high-income will double.

In Russia, the ratio of the number of employees and the number of pensioners are not only smaller, but also expected to decline from 1.3 in 2013 to 1.2 in 2020, and since 2040 will become negative: 0.95 and even to 2050 will be 0.9 . All this requires the search for new sources of financing the well-being of pensioners.

Pensioners are invited to align the level of consumption during life, choosing between consumption in young or old age, as well as to compensate the reduction in the yield of pension systems by personal savings. It is expected that in the future saving system, which stimulates the personal savings, there will be an integral part of any pension system.

In this situation we can formulate several versions for the reform of the pension system:

- to return to the pension systems of the last century (the 70-s), as the preservation of the current situations requires significant additional efforts of all participants: the state, employers and retirees. The key purposes of the pension system reform differ from each other and include: 
- the maximum protection for senior citizens, at least the guaranteed minimum income (Chile, Bolivia, etc.);

- reducing tensions of public finances: reducing the budget deficit and the governmental debt (Poland, Hungary, Slovakia and other countries of Central and Eastern Europe). As a large part of assets private pension funds invest into governmental bonds to cover particularly the deficit caused by the direction of the contributions to private pension funds, the Polish government, for example, not only reduced the contribution rate to the funded part of the system from 7.3 to $29 \%$ of salary, but also participated in its voluntarily. Since 2014 all assets have been held in governmental bonds and insured. There was also introduced a ban on any further investments funded by the part of pensions (Hirose, 2015);

- the guarantee of a socially acceptable pension fund scheme level; providing long-term financial stability of the pension system; retention at an acceptable level of insurance pension system load on the economy of the country (Russia) (http://base.garant.ru/70290226/).

- $\quad$ increasing taxation on labor income citizens of working age (i.e. business);

- $\quad$ increasing the length of employment, i.e., at actual retirement age;

- $\quad$ attracting immigrants of working age.

Studies on the various decisions and processes evaluated best practices and identified problems (http://www.eurofound.europa.eu/docs/eiro/tn1304032s/tn1304032s.pdf), but there is no solution that will work in any country; each country must find a solution that meets its specific social and political conditions. Moreover, no proposed solutions are simple and unique, since they are based on the attempt to ensure fairness, and it concerns not only the present, but also future pensioners. A justice, as it is well known, is not achievable: something which is always "true" to some is "not fair" for others. On the other hand, shortage of qualified personnel encourages older people to continue working, which also helps to improve their well-being, and not only material one.

Social injustice of the Russian's pension system is shown; in particular, more than $30 \%$ of pensioners are persons who appointed retirement pension ahead of time due to the particular and special conditions of work. In such a case the source is common funds of the RF PF rather than premiums of employers. The right for pensions is granted without reference to the actual conditions of work, health indicators and working ability of employees.

Another problem is a replacement rate, i.e. the ratio of pensions and salaries. The replacement rate cannot be less than $40 \%$ by the recommendations of the International Labour Organization (ILO). In Russia, in 2002 it was $34 \%$, by the 2007 it decreased to $25 \%$, in view of lag the rate of indexation of labor pensions of salary growth, and by the 2012 it increased to $36.8 \%$, i.e., it rank below the level recommended by the ILO, almost $10 \%$.

None of the traditional sources of seniors' income (employment yield of working age (pensions), personal savings and family assistance, payments from his own pocket and public services in cash or in non-monetary form) does not guarantee the achievement of well-being. So,

1. just over half (51.5\%) of people of retirement age receive a retirement pension (excluding China 45.6\%). Despite the increase in pension fund scheme in many countries, a significant regional disparity 
persists and is as follows: $16.9 \%$ - south of Sahara in Africa; $29.5 \%$ - in the Near-East; 36.7\% - in Asia; $47.0 \%$ - in North Africa; 32.4\% - in the countries of the Pacific; 56.1\% - in Latin America and the Caribbean; $90 \%$ or more - in North America and Europe. Public pension system (59\% of total pension income to middle-income and $80 \%$ - low), as well as health care and long-term care (free or at low rates) are not always available and are not always sufficient to achieve well-being.

2. The more older people get, the more they are for some reason can less and less rely on income from employment; even highly skilled are not guaranteed indefinitely income and access to wellpaying jobs. This source of income can reach $24 \%$ of pensioner's income with high yields, but just 5 $9 \%$ of those who have low incomes.

3. Payments out of pocket for long-term care, even in European countries are on average 9.6\% of income elderly, but can reach $25 \%$. Particularly affected are the poor and people are deeply older $(80+)$ women whose cexpenditures to seven times higher than that of 65 - 79 - year.

4. Personal assets (17\% of the total pensioner's income - bank deposits, securities, real estate, works of art. Philately and Numismatology, etc.) could improve the situation, but for most people they are, for various reasons (low income in working age, lack of investment traditions and financial literacy, lack of confidence in the banking system, the hope of state) not available.

5. To help the family can expect not all, as part of the family is also fighting for survival.

Of course, the serious question is the correlation of (the role of) the participation of these entire source in providing of well-being. In many countries of South and Southeast Asia due to the mentality believe that it is necessary to minimize government expenditures and put off the financial burden on the private sector. (Hagemejer, 2005) Similar approaches are available in India, Singapore and China, where adult children are legally responsible for providing care to needy parents threatened with prison or fines.

\section{Empirical testing of hypotheses}

Does the pension system of Russia provide decent living standard of unemployable citizens, regardless of the territory of residence?

Territorial differentiation of pensions is incorporated in the core document, which establishes the connection of the guaranteed minimum level of material support for pensioners with the value of pensioner's cost living of the Russian Federation, and the establishment of the pension at a level no lower than the 2.5-3 cost of living in the country until the scheduled, although it is according to the goals of justice and a federal state.

To detect the presence / absence of differentiation in the state social support senior citizens, we will assess eight federal districts of the Russian Federation for the period 2006-2011 for six indicators, including.:

- 3 "non-cash" - the number of elderly people: the list in institutions of social services (the absolute value and coefficients with the MinMax method) living in special homes for single elderly, are at a constant bed rest in hospital social service institutions.

- 3 "monetary": the correlation of pensions to the cost of living, the share of salary and social benefits in the total income, the share of property income in total income. 
Since the units of measurement indicators - are different, the data comparability required to translate them into the coefficients in this study - using the MinMax method. This method involves the following:

1. If higher values are preferable ( for example, the correlation of pension to cost of living and other "monetary" indicators), then the calculation is made by the formula (MinMax):

(Provincial Value - Min (Range of Provincial Values))

(Max (Range of Provincial Values) - Min (Range of Provincial Values))

2. If lower values are preferable (for example, all "non-monetary" indicators), the formula is adjusted as follows:

(Max (Range of Provincial Values) - Provincial Value)

(Max (Range of Provincial Values) - Min (Range of Provincial Values))

- the fraction multiplied by 10 (Bertranou, 2012 and Eurofound, 2013), since each indicator is received by the standard score on a scale from 0 to 10 .

We have divided the indicators into 2 groups, for "money" indicators it is necessary to use the formula (Bertranou, 2012), as higher values are preferable, and for "non-cash" - the formula (Eurofound, 2013), as there are preferable lower values.

To illustrate we give the calculation of the coefficient only one of the three selected indicators - "the number of senior citizens and the disabled persons for list in residential social service institution" (Table. 1). In the Siberian Federal District (SFD) in 2006, the number of such citizens was 40895 people; in CFD - 72571 (the worst measures); in the Far East - 15930 (the best index). We calculate the coefficient of the SFO from the formula (Eurofound, 2013), comparing it with the best and the worst federal district; it was 5.59 (Table. 1, column 2):

(72 $571-40895)$

$\times 10=5,59$

$(72571-15930)$

Table 1. The number of senior citizens and the disabled persons for list in residential social service institution (calculated by [15])

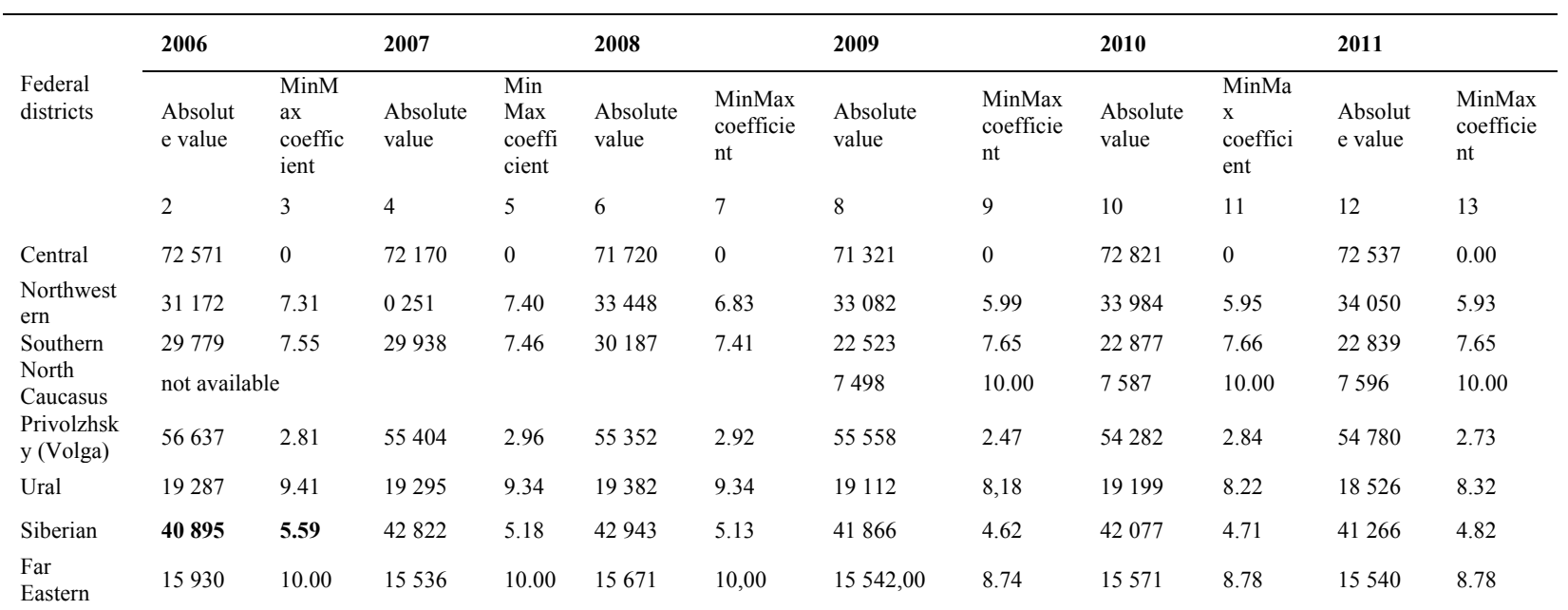




\begin{tabular}{llccccc}
$\begin{array}{l}\text { Maximum } \\
\text { rating }\end{array}$ & $\mathbf{7 2 5 7 1}$ & 72170 & 71720 & 71321 & 72821 & 72537 \\
$\begin{array}{l}\text { Minimum } \\
\text { rating }\end{array}$ & $\mathbf{1 5 9 3 0}$ & 15536 & 15671 & 7498 & 7587 & 7596 \\
\hline
\end{tabular}

To illustrate the next stage of empirical research we group the carried out calculations in 2011 and the "non-monetary" (Table. 2), and money (Table. 3) indicators.

Table 2. State social support, 2011 ("non-monetary", MinMax coefficient)

\begin{tabular}{|c|c|c|c|c|c|}
\hline \multirow[b]{2}{*}{ Federal districts } & \multicolumn{3}{|l|}{ Total activities } & \multicolumn{2}{|l|}{ Total activities } \\
\hline & $\begin{array}{l}\text { The number of } \\
\text { senior citizens } \\
\text { and the disabled } \\
\text { persons for list } \\
\text { in residential } \\
\text { social service } \\
\text { institution }\end{array}$ & $\begin{array}{l}\text { The number of } \\
\text { persons living } \\
\text { in special old } \\
\text { people's home }\end{array}$ & $\begin{array}{l}\text { The number of } \\
\text { senior citizens and } \\
\text { the disabled persons } \\
\text { who are at a } \\
\text { constant bed rest in } \\
\text { residential social } \\
\text { service institution }\end{array}$ & Total & Coefficient \\
\hline 1 & 2 & 3 & 4 & $5=\operatorname{SUM}(2: 4)$ & $6-\operatorname{MinMax}(5)$ \\
\hline Central & 0.00 & 5.54 & 0.00 & 5.54 & 0.00 \\
\hline Northwestern & 5.93 & 0.62 & 6.58 & 13.13 & 3.18 \\
\hline Southern & 7.65 & 10.00 & 7.58 & 25.23 & 8.24 \\
\hline North Caucasus & 10.00 & 9.43 & 10.00 & 29.43 & 10.00 \\
\hline Privolzhsky (Volga) & 2.73 & 0.00 & 2.83 & 5.56 & 0.01 \\
\hline Ural & 8.32 & 1.36 & 8.63 & 18.31 & 5.35 \\
\hline Siberian & 4.82 & 0.47 & 5.45 & 10.74 & 2.18 \\
\hline Far Eastern & 8.78 & 5.73 & 9.37 & 23.88 & 7.68 \\
\hline
\end{tabular}

Table 3. State social support, 2011 г. («monetary», MinMax coefficient)

\begin{tabular}{|c|c|c|c|c|c|}
\hline \multirow[b]{2}{*}{ Federal districts } & \multicolumn{2}{|l|}{ Total activities } & \multicolumn{3}{|c|}{ Total activities } \\
\hline & $\begin{array}{l}\text { Pension/cost of } \\
\text { living ratio }\end{array}$ & $\begin{array}{l}\text { The share of } \\
\text { remuneration of } \\
\text { labor and social } \\
\text { benefits in the } \\
\text { total yield }\end{array}$ & $\begin{array}{l}\text { The share of } \\
\text { property income in } \\
\text { the total yield }\end{array}$ & Total & Coefficient \\
\hline 1 & 2 & 3 & 4 & $5=\operatorname{SUM}(2: 4)$ & 6 - MinMax (5) \\
\hline Central & 6.90 & 10.00 & 10.00 & 26.9 & 10.00 \\
\hline Southern & 5.03 & 9.28 & 9.28 & 23.59 & 8.51 \\
\hline North Caucasus & 10.00 & 0.60 & 0.60 & 11.2 & 2.93 \\
\hline Privolzhsky (Volga) & 7.23 & 4.22 & 4.22 & 15.67 & 4.94 \\
\hline Ural & 6.75 & 3.43 & 3.43 & 13.61 & 4.01 \\
\hline Siberian & 5.68 & 0.00 & 0.00 & 5.68 & 0.44 \\
\hline Far Eastern & 0.00 & 2.35 & 2.35 & 4.7 & 0.00 \\
\hline
\end{tabular}

Further study require the same calculation for all years for the "non-cash" (Table. 4), and monetary indicators, which we had (tab. 5, Fig. 1).

Table 4. State social support, 2011 г. («non-monetary», MinMax coefficient)

\begin{tabular}{lllllll}
\hline Federal districts & $\mathbf{2 0 0 6}$ & $\mathbf{2 0 0 7}$ & $\mathbf{2 0 0 8}$ & $\mathbf{2 0 0 9}$ & $\mathbf{2 0 1 0}$ & $\mathbf{2 0 1 1}$ \\
\hline Central & 0.48 & 10.00 & 10.00 & 10.00 & 10.00 & 10.00 \\
Northwestern & 10.00 & 1.72 & 8.12 & 0.75 & 2.06 & 0.56 \\
Southern & 0.00 & 6.16 & 3.54 & 6.24 & 5.56 & 8.51 \\
North Caucasus & 1.87 & 5.13 & 8.44 & 5.39 & 4.62 & 2.93 \\
Privolzhsky (Volga) & 7.06 & 4.60 & 7.29 & 7.61 & 4.39 & 4.94 \\
Ural & 3.76 & 4.51 & 5.04 & 2.76 & 3.84 & 4.01 \\
Siberian & 3.22 & 3.54 & 4.22 & 1.18 & 2.03 & 0.44 \\
Far Eastern & 0.60 & 0.00 & 0.00 & 0.00 & 0.00 & 0.00 \\
\hline
\end{tabular}

Table 5. State social support, 2006-2011 (cash support - sum of MinMax)

\begin{tabular}{|c|c|c|c|c|c|c|}
\hline Federal districts & 2006 & 2007 & 2008 & 2009 & 2010 & 2011 \\
\hline
\end{tabular}


http://dx.doi.org/10.15405/epsbs.2016.02.30

eISSN: 2357-1330 / Corresponding Author: Eremina S.L., Email: esofia@tpu.ru

Selection and peer-review under responsibility of the Organizing Committee of the conference

\begin{tabular}{|c|c|c|c|c|c|c|}
\hline Central & 0.29 & 0.14 & 0.00 & 0.25 & 0.00 & 0.00 \\
\hline Northwestern & 6.15 & 5.83 & 6.56 & 4.85 & 4.40 & 3.18 \\
\hline Southern & 8.45 & 8.65 & 8.54 & 8.16 & 8.20 & 8.24 \\
\hline North Caucasus & 2.74 & 2.80 & 2.59 & 10.00 & 10.00 & 10.00 \\
\hline Privolzhsky (Volga) & 0.00 & 0.00 & 0.78 & 0.00 & 0.82 & 0.01 \\
\hline Ural & 7.15 & 7.83 & 7.87 & 5.82 & 5.80 & 5.35 \\
\hline Siberian & 2.64 & 2.51 & 2.10 & 2.20 & 2.05 & 2.18 \\
\hline Far Eastern & 10.00 & 10.00 & 10.00 & 8.02 & 7.87 & 7.68 \\
\hline
\end{tabular}

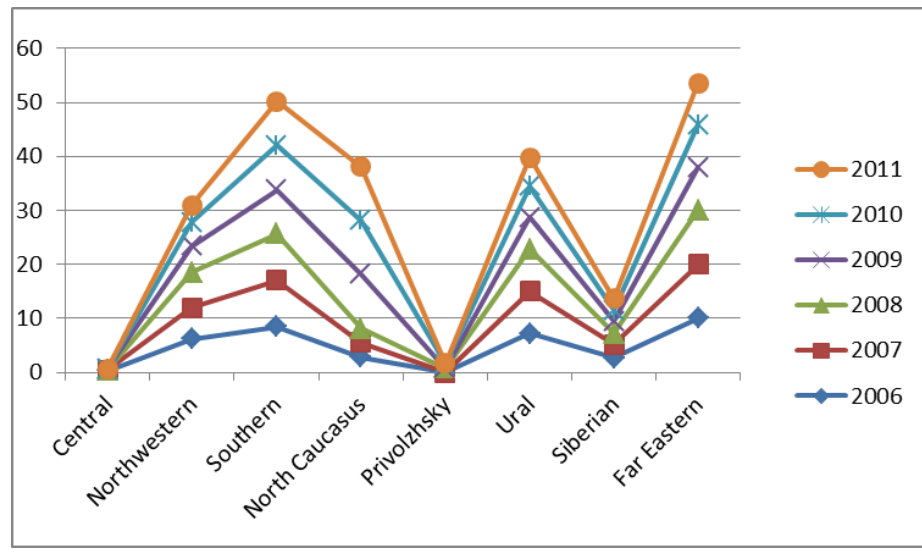

Fig.1. State social support, 2006-2011 (“monetary"- MinMax coefficient)

It would seem that there should obtain a symmetrical to previous picture, but in fact there is can be stated mixed trends in federal districts, which disproves of government support. For example, in the Central and Volga federal districts for 6 years, nothing has changed: the level of support remained unchanged. In the SFO he grew slightly. Stick-out in terms of state social support is the Southern and Far Eastern Districts. The remaining three federal districts are somewhere in the middle.

Following the stated problem, we compare the findings and expected change index in the financial situation (tab. 6, Fig. 2).

Table 6. Expected change index in the financial situation of an constituent entity, the Federal District of the Russian Federation, 2006-2010., MinMax coefficient

\begin{tabular}{llllllll}
\hline Year & Central & $\begin{array}{l}\text { Northwest } \\
\text { ern }\end{array}$ & Southern & Privolzhsky & Ural & Siberian & $\begin{array}{l}\text { Far } \\
\text { Eastern }\end{array}$ \\
\hline 2006 & 0 & 6.96 & 7.43 & 2.52 & 10 & 3.68 & 5.04 \\
\hline 2007 & 0 & 6.88 & 7.01 & 6.97 & 10 & 9.99 & 6.91 \\
\hline 2008 & 0 & 6.86 & 9.42 & 6.85 & 9.26 & 10 & 8.69 \\
\hline 2009 & 0 & 1.24 & 5.61 & 6.32 & 10 & 5.12 & 5.33 \\
\hline 2010 & 0 & 7.94 & 6.46 & 3.92 & 10 & 6.21 & 7.63 \\
\hline
\end{tabular}

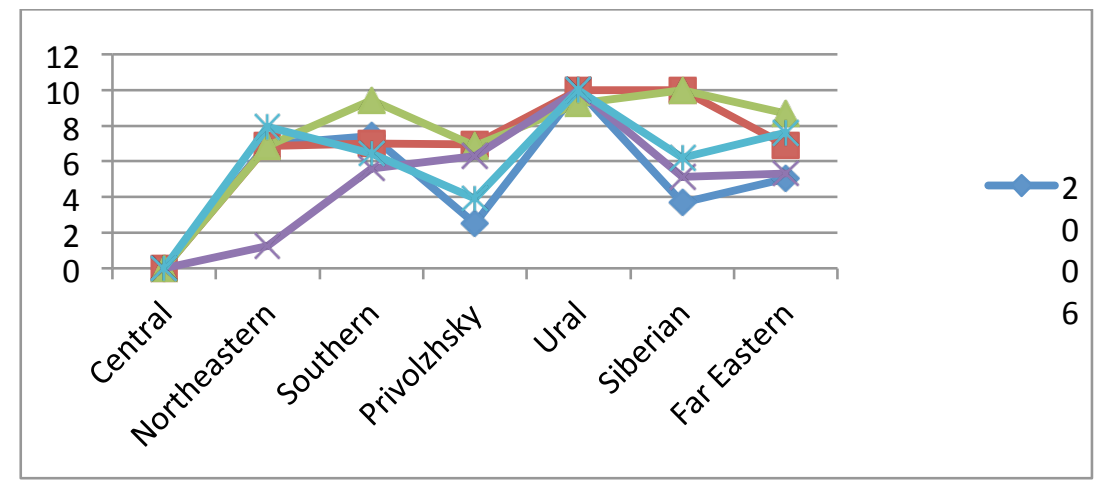


Fig.2. Expected change index in the financial situation, 2006-2010, Federal Districts of Russian Federation, MinMax coefficient

The figure allow for uniquely associate financial situation over the years of the crisis, i.e., prove procyclicality. If we keep in mind 2008 as the beginning of the crisis and to suppose that the effects had begun in 2009, the level of expectations of change in the financial situation in 2008, clearly above all years, and in 2009 - clearly below. None of the federal districts are not traced unidirectional dynamics of this index, except, perhaps, the Urals Federal District, where the rate remained virtually unchanged throughout the study period in 2009, despite the crisis, above those of 2008. All the more so there is no correlation with the levels of state support, both on "monetary", and on "non-monetary" activities, which may argue that:

- There is not available entity of social and pension support for citizens of Russia, it is substantively different for a variety federal districts;

- $\quad$ social and pension policy in Russia is not stable;

- despite the paternalism of the Russian state policy, older citizens do not really rely on the state.

\section{Conclusion}

Reducing of inequalities through pension and social security can and should bring benefit elderly, relieve the burden on poor households and provide additional income.

The calculations show that in the crisis of 2008 and the post-crisis 2009 pension and social support not only did not increase, and in some federal districts of Russia even declined. State support, both in cash and by "non-cash" activities is characterized in that:

- There is no unity of social and pension support for citizens of Russia, it is significantly different in variety of federal districts

- Russian social and pension policy is not stable

- Despite the paternalism of the Russian state policy, older citizens do not really rely on the state.

Therefore, it is necessary to improve social support for pensioners and the key focus here should be a leveling of differences, which corresponds to the constitutional goals federated state and is fair to the older people.

\section{Acknowledgements}

This work is done on the basis of the Ministry of Education and Science of the Russian Federation within the project in Evaluation and enhancement of social, economic and emotional wellbeing of older adults under the Agreement No.14.Z50.21.0029

\section{References}

Bertranou, F. (ed.). 2012. Beyond the privatization and re-nationalisation of the Argentine pension system: Coverage, fragmentation, and sustainability, Social Science Research Network Working Paper, Nov. Available at: http://ssrn.com/abstract=2191202 [16 Apr. 2014].

Eurofound (European Foundation for the Improvement of Living and Working Conditions). 2013. Social partners' involvement in pension reform in the $\mathrm{EU}$ (Dublin). Available at: http://www.eurofound .europa.eu/docs/eiro/tn1304032s/tn1304032s.pdf [16 Apr. 2014].

Sarfati, H.; Ghellab, Y. 2012. The political economy of pension reforms in times of global crisis: State unilateralism or social dialogue?, Working Paper No. 37 (Geneva, ILO). Available at: 
http://www.ilo.org/ifpdial/information-resources/publications/WCMS_176346/lang-en/index.htm [20 Apr. 2014].

Hagemejer, K. 2005. Sustainable, safe and adequate pensions in the ageing society: Policy dilemmas, in Polityka Społeczna, 1(1), 11-17.

Hagemejer, K.; McKinnon, R. 2013. "The role of national social protection floors in extending social security to all", in International Social Security Review, 66(3-4), 3-19.

HelpAge International: HelpAge's social pension's database. Available at: http://www.pension-watch.net/ aboutsocial-pensions/about-social-pensions/social-pensions-database/ [6 June 2014]

Hirose, K. (ed.). 2011. Pension reform in Central and Eastern Europe in times of crisis, austerity and beyond (Budapest, ILO Regional Office for Central and Eastern Europe)

Bertranou, F.; Cetrángolo, O.; Grushka, C.; Casanova, L. 2012. Beyond the privatization and re-nationalisation of the Argentine pension system: Coverage, fragmentation, and sustainability, Social Science Research Network Working Paper. Available at: http://ssrn.com/abstract=2191202 [16 Apr. 2014].

How's Life? Measuring well-being. Available at: www.oecdbetterlifeindex.org

Jamaluddina S.Z., Chuana G.C., Taherb M.A. (2015) Strategies in the Prevention or Reduction of Elder Abuse in Bangladesh and Malaysia, Procedia - Social and Behavioral Sciences 172, 42-48.

Mabahwi N.A., Leh O.L., Omar D. (2014) Human Health and Wellbeing: Human health effect of air pollution Procedia - Social and Behavioral Sciences 153, 221-229

The inverting pyramid. Pension Systems in Europe and Central Asia. 2014. World Bank. Available at: http://documents.worldbank.org/curated/en/2014/01/18941323/inverting-pyramid-pension-systems-facingdemographic-challenges-europe-central-asia-vol-2-2-main-report

World Social Protection Report 2014-15,336 p. International Labor Office 2014. Available at: http://www.ilo.org/documents/publication/wcms_245201.pdf

Poverty and inequality in modern Russia: 10 years later, Analytical report of the Institute of Sociology in cooperation with the Friedrich Ebert Foundation in the Russian Federation Moscow 2013. Available at: http://www.isras.ru/analytical_report_bednost_i_neravenstva.html

The Universal Declaration of Human Rights. Adopted by General Assembly resolution 217 A (III) of the General Assembly of the United Nations on December 10,1948. Available at: http://www.un.org/ru/documents/decl_conv/declarations/declhr.shtml

Global AgeWatch Index 2014: RESEARCH REPORTS 28. Available at: www.globalagewatch.org

Sarfati, H.; Ghellab, Y. 2012. The political economy of pension reforms in times of global crisis: State unilateralism or social dialogue?, Working Paper No. 37 (Geneva, ILO). Available at: http://www.ilo.org/ifpdial/information-resources/publications/WCMS_176346/lang-en/index.htm [20 Apr. 2014].

United interagency information-statistical system. The Ministry of Health of the Russian Federation as of April 2015. Available at: http://www.fedstat.ru/indicator/data.do

The best countries for retirees. 2013. Available at: http://www.euromag.ru/catalogs/stat/30691.html

International Covenant on Economic, Social and Cultural Rights adopted resolution 2200 human A (XXI) of the General Assembly on December 16, 1966. Available at: http://www.un.org/ru/documents/decl_conv/conventions/pactecon.shtml

On Introducing Amendments to Certain Legislative Acts of the Russian Federation on mandatory pension insurance in terms of the right to choose the insured option pensions. The Federal Law of 04.12.2013, 351-FZ. Available at: http://www.consultant.ru/document/cons_doc_LAW_171753/

On Introducing Amendments to the Federal Law "On state pension funds" and some legislative acts of the Russian Federation. The Federal Law of 01.12.2014 N 410-FZ. Available at: http://www.consultant.ru/document/cons_doc_LAW_171564/

On guaranteeing the rights of the insured persons in the mandatory pension insurance system of the Russian Federation in the formation and investment of pension funds, the establishment and implementation of the payments due to the pension savings. The Federal Law of 28.12.2013, \# 422-FZ. Available at: http://www.rg.ru/2013/12/30/pens-dok.html

On minimum standards of social security. Adopted in Geneva on 06/28/1952 at the 35th session of the General Conference of the ILO. Available at: http://ppt.ru/newstext.phtml?id=15557

On the minimum levels of social protection. Adopted in Geneva on 14.06.2012 at the 101st session of the General Conference of the ILO. Available at:

http://base.consultant.ru/cons/cgi/online.cgi?req=doc;base=INT; $=57202$

Defined Contribution Pension system. The Federal Law of 28.12.2013, \# 424-FZ.

Disablement allowance, Old-Age benefits and Survivor's benefit. Adopted in Geneva on 29/06/1967 at the 51st session of the General Conference of the ILO. Available at:

http://base.consultant.ru/cons/cgi/online.cgi?req=doc;base=INT; $n=16209$

On the results of the expert group on the assessment of the cost-effectiveness of the federal budget and presentation of proposals for their optimization. Final Report NRU "Higher School of Economics" and VPO "Russian Presidential Academy of National Economy and Public Administration». Available at: http://www.slideshare.net/gridnev/ss-25894732

Insurance Pensions. The Federal Law of 28.12.2013, \# 400-FZ

On labor pensions in the Russian Federation. The Federal Law of 17.12.2001 N 173-FZ (ed. By 12.28.2013, as amended. From 04.06.2014). Available at: http://www.consultant.ru/document/cons_doc_LAW_156911/

United Nations, Department of Economic and Social Affairs, Population Division (2013). The future of the 
eISSN: $2357-1330$

Selection \& Peer-review under responsibility of the Conference Organization Committee

world's population: reissue 2012, release on DVD.

The cost of protecting senior citizens in the total population, 2010/11. The database of the Department of Social Protection ILO. Available at: http://www.social-

protection.org/gimi/gess/RessourceDownload.action?ressource.ressourceId=39237

The development strategy of the pension system of the Russian Federation until 2030. Approved by the Federal Government on 25.12.2012, 2524-p. Available at: http://base.garant.ru/70290226/ 